\title{
Groundwater Characterization and Salinity Intrusion Studies using Electrical Resistivity Survey (ERS)-Winder, Balochistan, Pakistan
}

Rudarsko-geološko-naftni zbornik

(The Mining-Geology-Petroleum Engineering Bulletin) UDC: $10.6 ; 551.1 / .4$

DOI: 10.17794/rgn.2022.1.4

Original scientific paper

\author{
Muhammad Irfan $^{1^{*}}$, Salma Hamza ${ }^{{ }^{*}}$, Muhammad Waqar Azeem ${ }^{2}$, Shaista Mahmud ${ }^{1}$, \\ Syed Nawaz-ul-Huda³, Anwar Qadir ${ }^{4}$ \\ ${ }^{\prime}$ Department of Earth and Environmental Sciences, Bahria University Karachif Campus, Karachi 75300, Pakistan \\ ${ }^{2}$ Department of Geology, Khushal Khan Khattak University, 27200, Khyber Pakhtunkhwa, Pakistan \\ ${ }^{3}$ Dawn GIS, Geospatial Statistical Research \& Analysis Division, Karachi 75300, Pakistan \\ ${ }^{4}$ Department of Earth Sciences, University of Haripur, 22620, Khyber Pakhtunkhwa, Pakistan
}

\begin{abstract}
Groundwater resources have always been explored for domestic use, livestock, and agriculture activities. In this study, the Winder area has been explored using the electrical resistivity method for understanding hydrogeological conditions. The study area is located along the coast of Balochistan. Schlumberger electrode arrays have been used to acquire vertical electrical sounding (VES) data for 23 stations. The field data is calibrated with a theoretical curve matching technique using software (IPI2WIN). The true resistivity, depths, thicknesses, aquifer attributes, and soil type have been extracted from the processed data. Pseudo-sections and geo-electrical lithology sections have been generated for the lateral distribution of hydrogeological settings. Furthermore, Dar-Zarrouk parameter calculations have been made and $3 \mathrm{D}$ surfaces are generated at $30 \mathrm{~m}$ and $60 \mathrm{~m}$ depth for transverse resistance (T), longitudinal conductance (S), and anisotropy $(\lambda)$. These parameters are plotted for resistivity distribution and coastal salinity intrusion analyses. The VES sounding results of o-110 m depth depict five layers mainly composed of silty sand, sandy clay, sand, and sandy gravel. The interpretation illustrates that freshwater unconfined aquifers are present in the quaternary sand and sandy gravel deposits. The water table is at a shallow depth along the river and deeper in the northeast further from the Winder River. The resistivity ranges between 29-1091 $\Omega-\mathrm{m}$ in layer-3, interpreted as the saturated zone. The approximate range of the water table is 19-40 $\mathrm{m}$. A value of T greater than 10000 shows fresh water and values below 8200 indicate salinity intrusion in the southwest towards the sea.
\end{abstract}

Keywords:

groundwater; vertical electrical sounding, winder; Dar-Zarrouk parameter; agricultural farm

\section{Introduction}

Water can be considered the single most important ingredient of life. Both surface and groundwater resources are therefore utilized for survival. Many countries around the globe in coastal areas are totally dependent upon groundwater utilization for domestic, industrial, and agricultural purposes due to dense population, particularly in arid and semi-arid regions (Barlow and Reichard, 2010; Dimitrios, et al., 2016; El Baba, et al., 2020). Overexploitation resulted in a saltwater intrusion in most of the coastal zones around the globe (Morgan and Werner 2015; Chen et.al., 2020). About $50 \%$ of the groundwater used in areas of developing countries has been derived from wells, springs, boreholes, and people who live there rely on such resources (Clarke et al., 1995). These resources are available in large quantities as compared to surface water and are hardly impact-

Corresponding author: Salma Hamza

salma.bukc@bahria.edu.pk ed by seasonal variation (Gopalakrishnan et., al 2020). Groundwater exploration is considered as one of the primary components of water management practices and each year around 700 billion cubic meters of groundwater are extracted from the earth aquifers (Hassan et al, 2017). Therefore, groundwater in water resource distribution is most vulnerable to depletion due to overexploitation. The rate of recharge that balances an aquifer is a slow process compared to the pumping rate of groundwater around the world (Famiglietti, 2014; Massoud et al., 2021).

Agriculture is considered as the backbone of any country because it directly influences the economy of countries. The agricultural production for food is highly dependent on the fertility of the soil as well as on the quality of the water (Abou El-Hassan et al., 2009; Kaçmaz and Nakoman, 2010). Pakistan is also an agricultural country whose economy relies on successful crops. Agricultural farms were established in 1993-94 near Winder town (Balochistan) in collaboration with 
the Department of Agriculture, Balochistan, and the Japanese government (see Figure 1). These farms lie above the Cretaceous ophiolitic rocks concealed by windblown sediments (see Figure 2). Due to the arid climate of the Winder area, the availability of water for agriculture purposes is a main concern. Winder River and groundwater are two main sources for irrigation in this area (Bashir et al., 2007). Winder Basin is a part of Lasbela Plain which is located near the Makran coast of Lasbela District, Balochistan. Porali River and its tributaries deposit alluvium sediments and form the triangular shape of Lasbela Plain (Spate, 1956). The width of this plain is about $64 \mathrm{~km}$ at the base and along the braided Porali River, it becomes narrow for almost $88 \mathrm{~km}$ towards the north. Winder River forms an estuarine delta at Miani Hor and drains the eastern part of the plain. The wide coastal sand dune belt present in the southwest of the study area formed because of strong winds. Alluvial silt and washouts by heavy precipitations cover the entire basin which is suitable for cultivation (Ahsanullah, 1971).

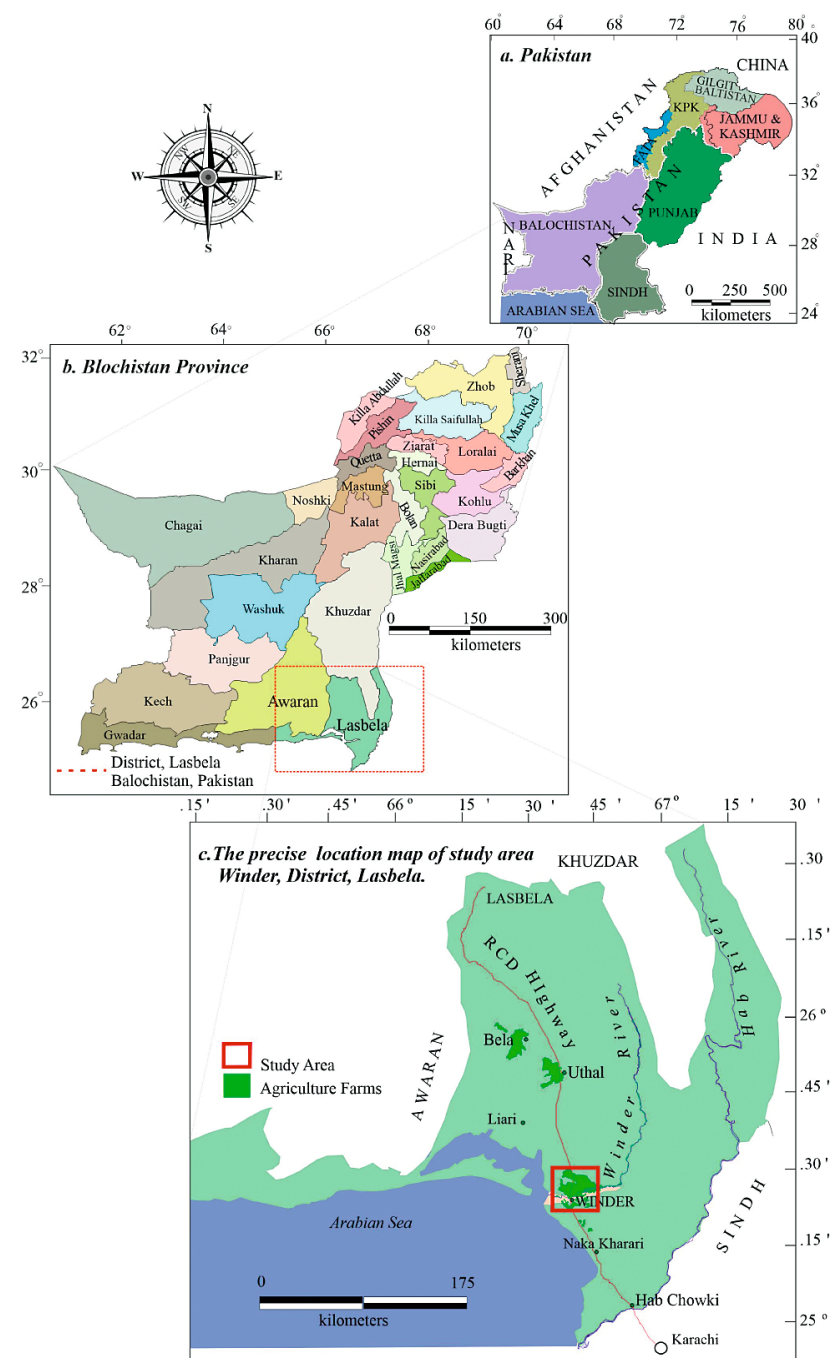

Figure 1: The location map of study area (a) Pakistan (b) Balochistan Province (c) District Lasbela, Balochistan.
The main objective of this research is to assess groundwater potential and hydrogeological conditions of the study area for sustainable groundwater management. The electrical resistivity method is used in this study as one of the suitable techniques to map the subsurface potential aquifers, thicknesses, and other hydrogeological conditions (Aoudia et al., 2020). The electrical resistivity method is useful, as it is an economical and efficient method for analyzing the presence of groundwater in the subsurface (Anomohanran, 2013). The electrical resistivity technique is gaining extensive applications in environmental geophysics, groundwater exploration, engineering geophysical investigations, and monitoring coastal environments (Afolayan and Olorunfemi 2004; Ihbach et al., 2020; Youssef et al., 2021; Muzzillo et al., 2021). The vertical electrical sounding (VES) method is feasible for subsurface imaging at greater depths (Benabdelouahab et al., 2019; Jamal et al., 2020; Kehinde et al., 2021). This method was introduced in 1934 by Schlumberger after which different arrays for this electrical resistivity method have been developed (Keller and Frischknecht, 1966). The prime concern of this inexpensive point measurement technique is to obtain the true resistivity for subsurface stratigraphy with saturation. In detail, the ultimate scope of VES is to resolve problems related to groundwater exploration, analysis, and assessment for aquifer thickness, aquifer depth, and lithological layer distributions (Zohdy 1969; El-Waheidi et al. 1992; Young et al. 1998; Choudhry et al. 2001; Soupios et al. 2007).

\section{Geology of the Study area}

Winder is located at the southern-most part of the western fold belt. Sedimentary rocks of Jurassic (Mor Range) and Cretaceous (Pab Range) in association with Bela ophiolites (Cretaceous) are exposed in the eastern part of the study area. Wind-blown sedimentary deposits in the west gradually conceal the ophiolites. Mor and Pab ranges are parallel, located in the east of the study area (see Figure 2). Rocks of Ferozabad Group (Jurassic) are exposed in Mor ranges, comprised of Kharrari, Malikhore, and Anjira formations. The rock's composition shows the siliciclastic and carbonatic depositional environment of Early-Middle Jurassic age (Shah, 1977). Ferozabad group rocks were deposited on the shelf flank of a rift system derived from the Gondwanaland breakup and the detachment of the Indian craton from Africa and Madagascar (Gnos et al., 1997). The limestone beds of the Kharrari and Malikhore formations contain stratabound replacement type deposits. Sedimentary exhalative mineralization (Sedex) is frequent in the upper part of the Anjira Formation. Sphalerite, pyrite, marcasite, and galena with minor chalcopyrite are associated with the sulfide mineralization (Ahsan and Mallick, 1999). The Sembar, Goru, Parh, Fort Munro, Mughal Kot and Pab formations are exposed in the Pab Range (Kazmi 
and Abbasi, 2008). The Bela ophiolite is associated with Alpine-Himalayan Mesozoic Ophiolitic Belt, which is $400 \mathrm{~km}$ long. It is a sub-type of ophiolite comprised of Harzburgite, which is usually in the Tethyan Domain. It has attributes of both supra-subduction zone and midoceanic ridge settings and is intruded by magmas-driven hotspots (Khan et al., 2007; Sheth, 2008). It is represented by Tholeitic basalts, Mafics and Ultramafics. Based on age and tectonic settings, Bela ophiolites are divided into two units. In the northern part of the belt, the upper unit is exposed between Sonaro and Wadh. The lower unit consists of trench sediments and ophiolite accretionary wedges that are well exposed from Sonaro to the coast of Karachi in the south and occasionally found along with the western contact of the Mor Range (Gnos et al., 1998).

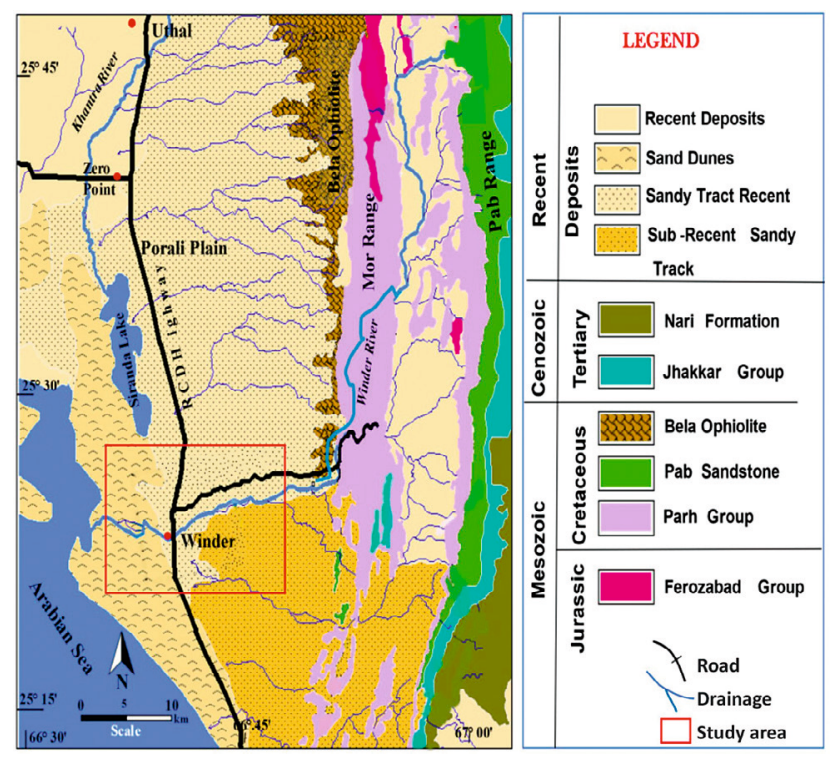

Figure 2: Geological Map of Winder and the adjoining area of Balochistan represent the exposed stratigraphy from

Mesozoic to Cenozoic, drainage pattern, and other geomorphological features of District Labsela, Balochistan, Pakistan (modified after HSC, 1960).

\section{Material and Methods}

The electrical resistivity method involves vertical electrical sounding (VES) which depends on estimating the potential drop in between the electrodes during the transmission of direct current (Frohlich, 1974). There are different types of electrical resistivity techniques depending on the electrode configuration. Wenner electrode configuration, Schlumberger electrode configuration, Pole-Dipole array, and Dipole-Dipole array, etc., can be chosen depending on the acceptable precision and availability of the labour (Telford et al., 1990). Mainly Wenner and Schlumberger electrode configuration techniques (see Figure 3) are extensively used for groundwater exploration (Solberg et al., 2008; Long et al., 2012). In Wenner electrode configuration, the four uniformly spaced collinear electrodes constitute a Wenner array. The outer electrodes are current electrodes or source electrodes, and the inner electrodes are potential electrodes or receiver electrodes. Equivalent spacing between each electrode is maintained about the array midpoint when array spacing is expanded. Apparent resistivity is easily calculated in the field using the Wenner array. The sensitivity of the Wenner instrument is not pivotal as with other array geometries. To produce quantifiable potential differences, relatively small magnitudes of current are required (Mali and Mujawar, 2019). Wenner array's disadvantages are that for each sounding, all electrodes must be moved to a new point. Longer current cables are required to image deep into the Earth. It is unwieldy to handle the electrodes and cables between each measurement, typically in difficult terrain. Near the surface, the Wenner array is sensitive for uniformities which may ask for new profound electrical responses. It is a labour-intensive data collection because of the long cable lengths and electrode movement is required during the survey. Cables of considerable lengths are galvanized with current at high voltage and present a safety risk (Hasan et al., 2017).

The Schlumberger configuration with a half spacing of the current electrode $(\mathrm{AB} / 2$ from 2 to 150 meters and $\mathrm{MN} / 2$ from 0.5 to 10 meters) was utilized in this survey (Frohlich, 1974). In the Schlumberger electrode configuration, the four collinear electrodes constitute the Schlumberger array. The outer electrodes are current electrodes or source electrodes, and the inner electrodes are potential electrodes or receiver electrodes. At the centre of the electrode array, potential electrodes are placed with a small separation, generally less than $1 / 5^{\text {th }}$ of the spacing of the current electrodes. During the survey, the separation between the current electrodes is in-

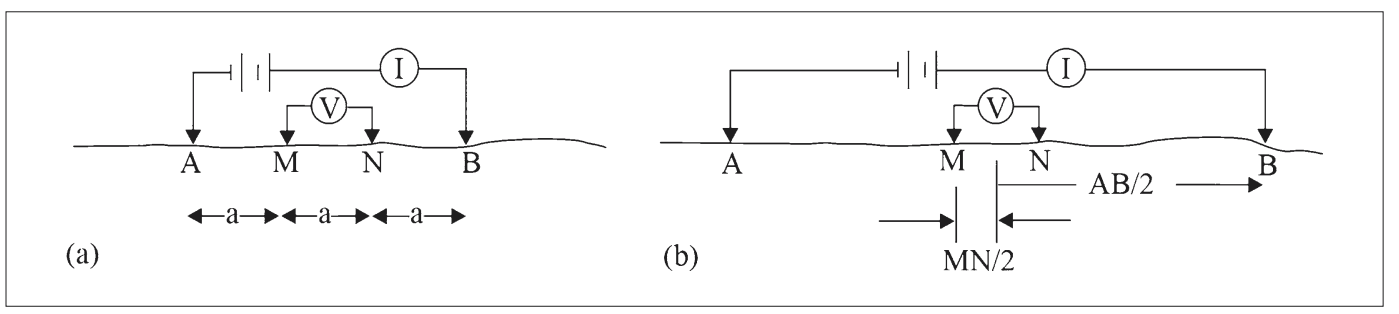

Figure 3: Electrical Resistivity Survey electrode configuration for geophysical data acquisition (a) Wenner array configuration (b) Schlumberger array (Rhett, 2001) 
creased while the potential electrodes remain in the same place until the observed voltage becomes too small to measure (Meindinyo et al., 2017). The Schlumberger array is convenient to use because for each sounding, fewer electrodes are required to be moved and a shorter length of cable is required for potential electrodes. Schlumberger soundings usually have an effective resolution, extensive probing depth, and a less time-consuming field layout than the Wenner array. The reconnaissance survey of the area was conducted to design a geophysical survey. In accordance with the desired objectives, the vertical electrical sounding data was acquired at 23 points, i.e. 23 different sites in the Winder area (see Figure 4).

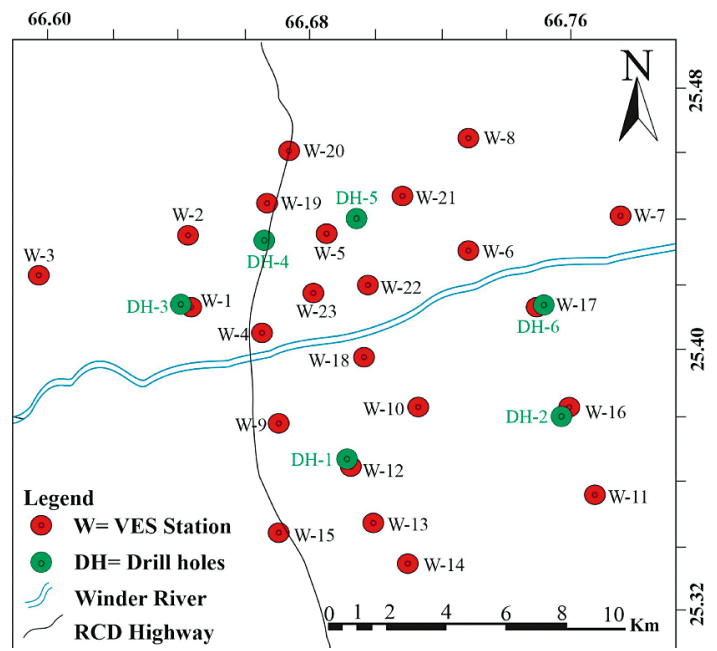

Figure 4: Location of acquired vertical electrical sounding (VES) station, drilled borehole points near the VES station.

The types of equipment utilized for the survey were a PASI-Earth (16 GLN) resistivity meter for acquiring vertical electrical sounding data in which the four electrodes were placed uniformly along a straight line where the current electrodes (A and B) were on the outside and the potential electrodes ( $\mathrm{M}$ and $\mathrm{N}$ ) were between $\mathrm{A}$ and B. The PASI earth resistivity meter was powered by a direct current (DC) source and spacing between the current electrodes is increased further outwards to get a pronounced probing depth while the potential electrodes remain static. Furthermore, the potential electrodes were moved outwards when the ratio of the distance between the current electrodes to that of the potential electrodes became substantial, or else the potential difference became insufficient to measure. The maximum current electrode spacing was kept at 300 meters (AB) for the depth penetration of 150 meters. The designed layout of the current electrode $\mathrm{AB}$ spacing for the VES station to readout the resistance value from the resistivity meter 2 , $4,6,8,10,10,15,20,25,25,30,35,40,45,50,50,60$, $70,80,90,100,100$, and $150 \mathrm{~m}$ and the potential electrode spacing $0.5,2,5,10,20$ and $50 \mathrm{~m}$. Readings were repeated to calculate the average resistance value with an increase in spacing of potential electrode, i.e. 10, 25,
$50 \mathrm{~m}$. The reason for increasing the space is that the potential contrast is excessively little and hard to gauge at large electrode spacing, therefore, the potential electrodes were moved while keeping the current electrode fixed. The measured resistance value was used to calculate the apparent resistivity by multiplying the acquired resistance values from the field with the respective Geometric factor (k) using Equation 1 and 2 by Keller and Frischknecht (1966).

$$
\mathrm{K} \pi=\left[\frac{\left[\frac{\mathrm{AB}}{2}\right]^{2}-\left[\frac{\mathrm{MN}}{2}\right]^{2}}{\left[\frac{\mathrm{MN}}{2}\right]^{2}}\right]
$$

Where:

$A B$ - distance between two current electrodes (m);

$M N$ - distance between two potential electrodes (m);

$\pi$ - constant value 3.142 ;

$K-$ geometric factor differs in the layout of current and potential electrodes.

$$
\rho a=K \times R
$$

Where:

$\rho a$ - apparent resistivity computing using ohms law $(\Omega \mathrm{m})$

$K$ - geometric factor differs in the layout of current and potential electrodes;

$R$ - resistance $(\Omega)$.

The field data was plotted on a log-log graph sheet for interpretation of apparent resistivity (y-axis) and current electrode spacing (x-axis). A curve is obtained which is known as a field curve, the most common practice of curve matching is applied in such a way that the field curve can be matched with the master curves (A, H, K, and Q). These master curves are available in the literature for two to three layers as an auxiliary graph. The procedure and theoretical background of curve matching are adopted as (Zohdy, 1965; Bhattacharya and Parta, 1968; Koefoed, 1979). The final curve with a maximum $6 \%$ root mean square (RMS\%) error is used for the interpretation of hydrogeological parameters using IPI2Win software. The accuracy of the results highly depends on the low percentage of RMS value (Zohdy, 1989). The same procedure is adopted for 23 VES stations in the study area. Matching of both the curves and layer modelling resulted in true resistivities of four layers, depth, and thickness at 23 VES stations.

The lithology logs are constructed using drill borehole cutting samples (see Figure 5). To calibrate the lithological interpretation of sounding curves (about the depth of $90 \mathrm{~m}$ ), boreholes located near the VES stations (W-1, W-5, W-12, W-16, W-17, and W-19) are used. Pseudo-sections have always been utilized for a better understanding of the lateral and vertical distribution of resistivity. In this study, pseudo-sections have been generated for the acquired VES profiles, which are collinear 

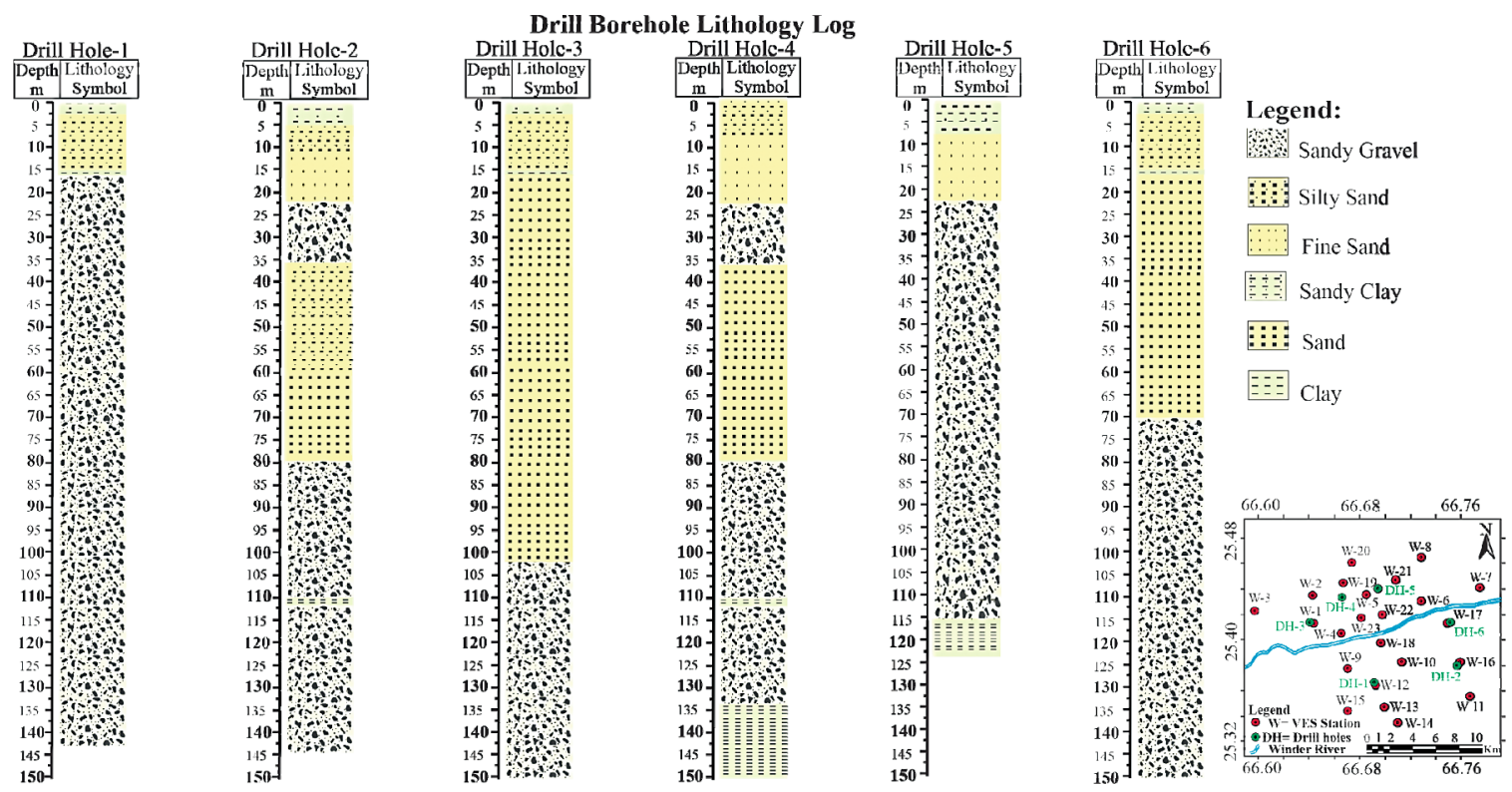

Figure 5: Lithology log acquired from six drilled borehole cutting samples.

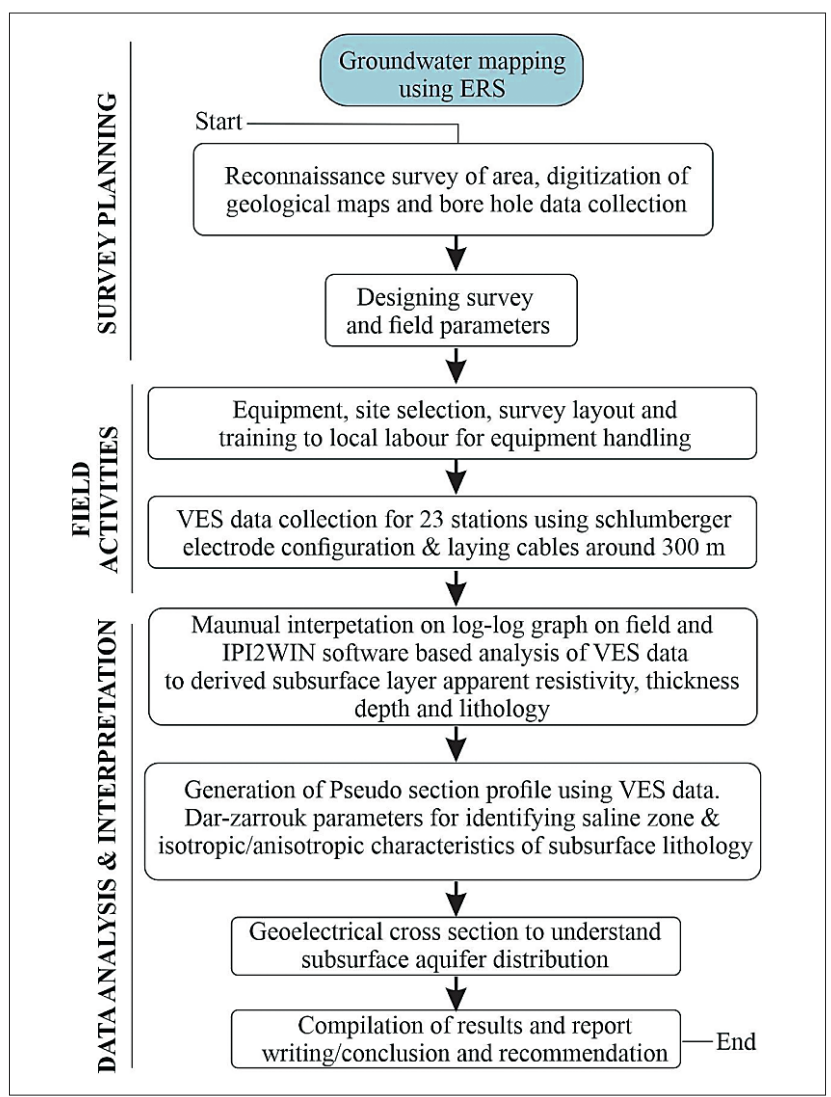

Figure 6: Methodology flowchart for groundwater mapping using Electrical Resistivity Survey

for generating a pseudo-section and resistivity section to portray the variation of resistivity along with the profiles. Three pseudo sections are generated along with three profiles, i.e. A- A', B - B', and C- C', by using 7 VES's in each profile.

Contour maps and 3D surfaces for Dar-Zarrouk (D-Z) parameters have been generated based on the true resis- tivity values and thicknesses. The $\mathrm{D}-\mathrm{Z}$ parameters have always been useful in delineating zones of salinity and monitoring lateral variation in heterogeneity (Hasan, 2019). The average electrical properties of each unit in a stratigraphic section can be characterized by D-Z parameters (Maillet, 1947). Transverse resistance (T) in DarZarrouk parameters is the resistance normal to face while longitudinal conductance $(\mathrm{S})$ is the resistance parallel to the face of the material in a unit cross-sectional area. Moreover, the D-Z parameters also help in differentiating the isotropic and anisotropic properties of subsurface lithology (Singh et al., 2004). Following these steps, further investigation has been made for understanding the hydrogeological profile; the geo-electric sections have been generated. These geo-electric sections present a correlation in two different profiles extending in the east-west and north-south directions. The methodological workflow of this study is presented to accomplish the objective (see Figure 6).

\section{Results \& Discussion}

The data of 23 VES stations have been collected in the Winder area. The results of 23 VES stations have been utilized for apparent resistivity curve interpretation, pseudo-section profiles and geo-electric sections generation, and Dar-Zarrouk parameter estimations. The detailed results and their discussions are given in the following sections.

\subsection{VES Station}

PASI-Earth (16 GLN) resistivity meters were used at 23 VES points to collect field data. Initially, the field data is plotted on log-log paper and matched with the master curve with a maximum of $6 \%$ error to model subsurface 
(a)

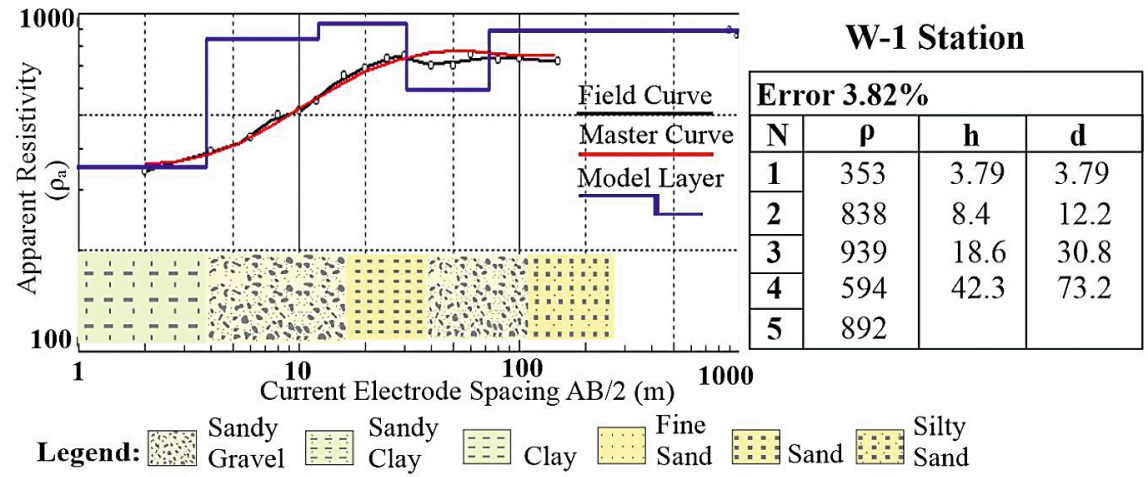

(b)

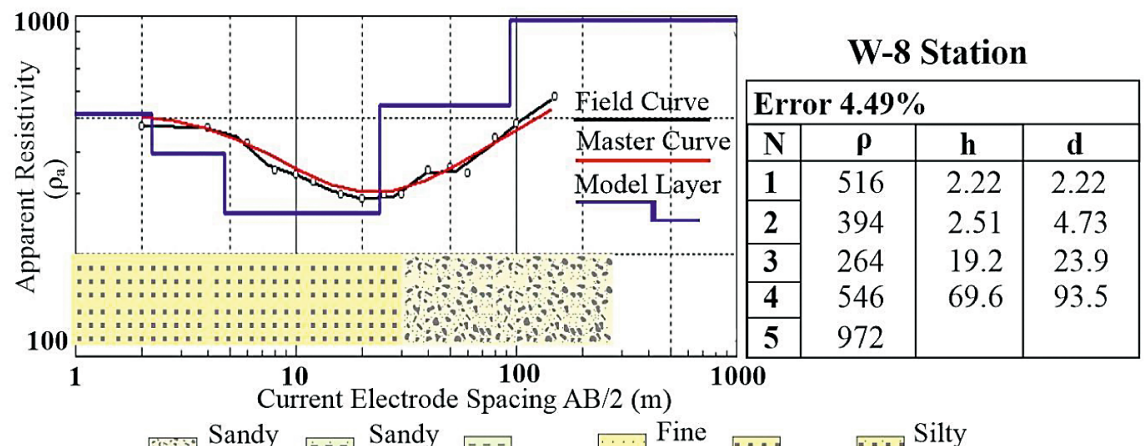

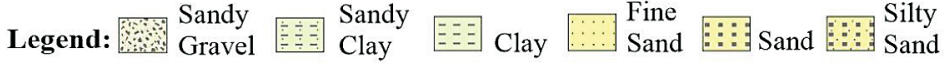

(c)

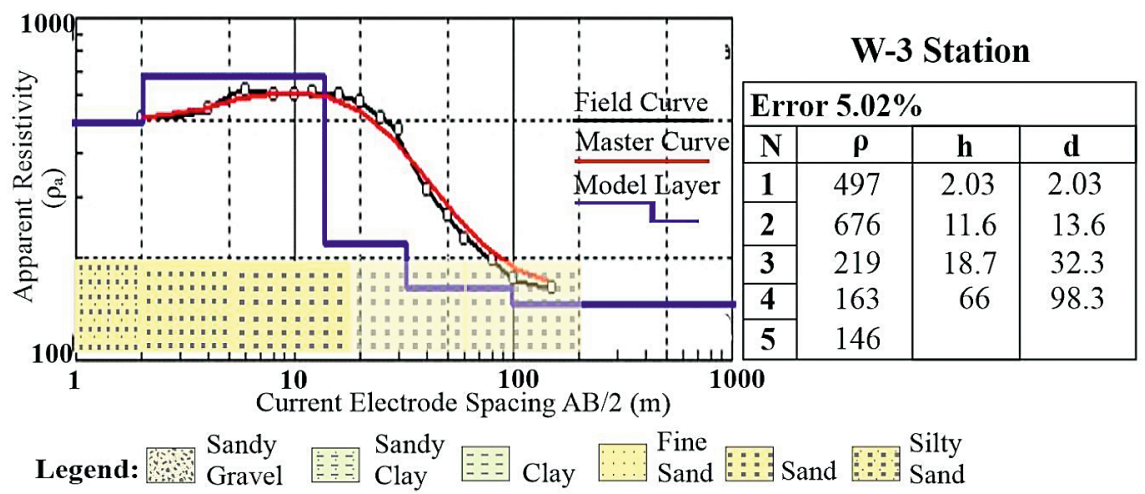

(d)

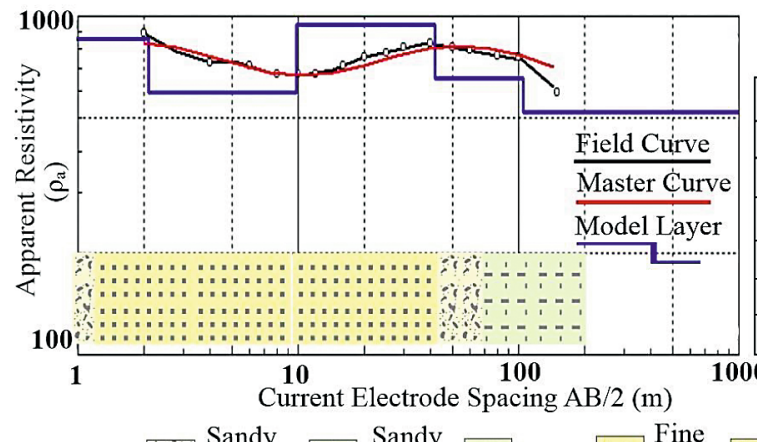

\section{W-11 Station}

\begin{tabular}{|c|c|c|c|}
\hline \multicolumn{4}{|c|}{ Error $5.07 \%$} \\
\hline $\mathbf{N}$ & $\rho$ & h & d \\
\hline 1 & 858 & 2.09 & 2.09 \\
\hline 2 & 596 & 7.72 & 9.81 \\
\hline 3 & 944 & 32 & 41.8 \\
\hline 4 & 656 & 63.1 & 105 \\
\hline 5 & 521 & & \\
\hline
\end{tabular}

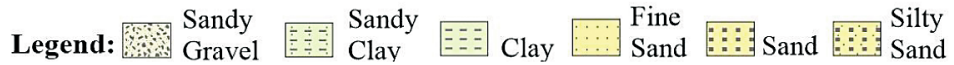

Figure 7: Vertical electrical sounding curve and derived layer characteristics using IPI2Win (lithology, apparent resistivity, thickness, and depth). (a) W-1 station (b) W-8 station (c) W-3 station (d) W-11 station.

layers. The interpretation exhibits that subsurface layers are mainly comprised of sand, clay, sandy clay, sandy gravel, and silty sand calibrated with the drill borehole.
The selected VES stations W-1. W-3, W-8, and W-11 represent high variation in apparent resistivity, thickness, and depth of the modelled layers (see Figure 7). 
Table 1: VES station coordinates and summary of IPI2Win results for resistivity $(\Omega \mathrm{m})$, thickness $(\mathrm{m})$ and depth (m).

\begin{tabular}{|c|c|c|c|c|c|c|c|c|c|c|c|c|c|c|c|}
\hline VES & Latitude & Longitude & $\rho_{1}$ & $\rho_{2}$ & $\rho_{3}$ & $\rho_{4}$ & $\rho_{5}$ & $h_{1}$ & $h_{2}$ & $h_{3}$ & $\mathrm{~h}_{4}$ & $d_{1}$ & $d_{2}$ & $d_{3}$ & $d_{4}$ \\
\hline W-1 & 25.4153 & 66.6466 & 353 & 838 & 939 & 594 & 892 & 3.79 & 8.4 & 18.6 & 42.3 & 3.79 & 12.2 & 30.8 & 73.2 \\
\hline W-2 & 25.4148 & 6.641 & 379 & 981 & 590 & 506 & 953 & 3.29 & 9.42 & 15.7 & 70.6 & 3.29 & 12.7 & 28.5 & 99 \\
\hline W-3 & 25.4228 & 66.5979 & 497 & 676 & 219 & 163 & 146 & 2.03 & 11.6 & 18.7 & 66 & 2.03 & 13.6 & 32.3 & 98.3 \\
\hline W-4 & 5.406 & 6.6659 & 266 & 163 & 917 & 348 & 299 & 1.23 & 1.31 & 16.5 & 62.6 & 2.13 & 3.45 & 20 & 82.5 \\
\hline W-5 & 5.4153 & 66.6466 & 144 & 579 & 779 & 708 & 1090 & 2.44 & 2.87 & 22.6 & 53.1 & 2.44 & 5.31 & 27.9 & 81 \\
\hline W-6 & 5.4302 & 66.7279 & 222 & 681 & 794 & 590 & 953 & 2.35 & 4.66 & 17.2 & 70.2 & 2.35 & 7.01 & 24.2 & 94.4 \\
\hline W-7 & 25.4413 & 66.7754 & 181 & 883 & 668 & 990 & 1144 & 1.27 & 11.4 & 38.4 & 49.9 & 1.27 & 12.7 & 51.1 & 101 \\
\hline W-8 & 25.4665 & 66.7299 & 516 & 394 & 264 & 546 & 972 & 2.22 & 2.51 & 19.2 & 69.6 & 2.22 & 4.73 & 23.9 & 93.5 \\
\hline W-9 & 25.3997 & 66.6894 & 431 & 764 & 926 & 743 & 981 & 1.69 & 5.05 & 31.9 & 49.6 & 1.69 & 6.75 & 38.7 & 88.3 \\
\hline W-10 & 25.382 & 66.7135 & 195 & 419 & 1029 & 536 & 656 & 2.61 & 2.21 & 43.9 & 52.3 & 2.61 & 4.82 & 48.7 & 101 \\
\hline W-1 1 & 5.3547 & 66.7677 & 858 & 596 & 944 & 656 & 521 & 2.09 & 7.72 & 32 & 63.1 & 2.09 & 9.81 & 41.8 & 105 \\
\hline W-12 & 25.3559 & 66.6918 & 136 & 637 & 810 & 874 & 944 & 1.96 & 8.73 & 20.9 & 70.3 & 1.96 & 10.7 & 31.6 & 102 \\
\hline $\mathrm{W}-13$ & 25.3559 & 66.6918 & 203 & 447 & 613 & 787 & 410 & 2.93 & 6.16 & 21.7 & 51.8 & 2.93 & 9.09 & 30.8 & 82.5 \\
\hline W-14 & 25.3346 & 66.7102 & 408 & 568 & 909 & 1090 & 1271 & 2.26 & 3.75 & 22 & 63.7 & 2.26 & 6.01 & 28 & 91.7 \\
\hline W-15 & 25.344 & 66.6713 & 728 & 781 & 484 & 644 & 728 & 2.75 & 4.15 & 27.3 & 61.2 & 2.75 & 6.9 & 34.2 & 95.5 \\
\hline W-16 & 25.3801 & 66.7586 & 485 & 1038 & 808 & 1108 & 1215 & 3.88 & 15.4 & 28.3 & 46.1 & 3.88 & 19.3 & 47.6 & 93.7 \\
\hline W-17 & 25.4132 & 66.7505 & 428 & 935 & 1091 & 742 & 572 & 1.96 & 11.4 & 34.7 & 51 & 1.96 & 13.4 & 34.7 & 51 \\
\hline W-18 & 25.3997 & 66.6894 & 63.6 & 271 & 647 & 834 & 1018 & 1.46 & 1.75 & 22 & 92.2 & 1.46 & 3.21 & 25.2 & 117 \\
\hline W-19 & 25.4348 & 66.664 & 198 & 696 & 911 & 659 & 930 & 1.9 & 7.96 & 29.8 & 58.5 & 1.9 & 9.86 & 39.7 & 98.2 \\
\hline W-20 & 25.4603 & 66.6734 & 452 & 707 & 825 & 557 & 937 & 2.33 & 7.94 & 15.8 & 96.2 & 2.33 & 7.94 & 15.8 & 96.2 \\
\hline $\mathrm{W}-21$ & 25.4425 & 66.6959 & 365 & 758 & 927 & 1065 & 1163 & 3.95 & 9.59 & 20.7 & 40.7 & 3.95 & 13.5 & 34.3 & 74.9 \\
\hline W-22 & 25.4244 & 66.6956 & 480 & 675 & 917 & 539 & 434 & 2.36 & 3.39 & 24.5 & 68 & 2.36 & 5.75 & 30.3 & 98.2 \\
\hline W-23 & 25.4228 & 66.6804 & 255 & 917 & 1048 & 1125 & 730 & 2.08 & 5.52 & 22.2 & 57 & 2.08 & 7.6 & 29.8 & 86.8 \\
\hline
\end{tabular}

\subsubsection{W-1 Station}

W-1 station consists of four geological layers where the topmost layer resistivity is $353 \Omega \mathrm{m}$ and it is interpreted as sandy clay present at a depth of 3.79 meters while layer 2 has a value of $838 \Omega \mathrm{m}$ which is sandy gravel present at a depth of 12.2 meters. Layer 3 has a resistivity value of 17.1 which is fine sand present at a depth of 30.8 meters while layer 4 has a resistivity value of $594 \Omega \mathrm{m}$ which is sandy gravel present at a depth of 73.2 meters. The curve type is AKH, i.e. $\rho 1<\rho 2<\rho 3>\rho 4<\rho 5$. W- 1 comprises a thick package of unconsolidated sand and a sandy gravel aquifer. These types of deposits have good intergranular porosity (Miller, 2000). A higher resistivity below $30.8 \mathrm{~m}$ shows the potential presence of a freshwater unconfined aquifer (see Figure 7a).

\subsubsection{W-8 station}

W-8 station depicts four geological layers in which the topmost layer resistivity is $516 \Omega \mathrm{m}$ and it is interpreted as silty sand at a depth of 2.22 meters while layer 2 has a value of $394 \Omega \mathrm{m}$ which is silty sand present at a depth of 4.73 meters. Layer 3 has a resistivity value of $264 \Omega \mathrm{m}$ which is silty sand present at a depth of 23.9 meters while layer 4 has a resistivity value of $546 \Omega$ which is sandy gravel present at a depth of 93.5 meters. The curve type is QHA, i.e. $\rho 1>\rho 2>\rho 3<\rho 4<\rho 5$. W-8 lithology contains a thick package of unconsolidated sand and sandy gravel. A higher resistivity below $23.9 \mathrm{~m}$ reveals the potential presence of an unconfined aquifer (see Figure 7b).

\subsubsection{W-3 station}

W-3 illustrates four geological layers in which the topmost layer resistivity is $497 \Omega \mathrm{m}$ and it is interpreted as fine sand at a depth of 2.03 meters while layer 2 has a value of $676 \Omega \mathrm{m}$ which is silty sand present at a depth of 13.6 meters. Layer 3 has a resistivity value of $219 \Omega \mathrm{m}$ which is silty sand present at a depth of 32.3 meters while layer 4 has a resistivity value of $163 \Omega \mathrm{m}$ which is silty sand present at a depth of 98.3 meters. The curve type is KQQ, i.e. $\rho 1<\rho 2>\rho 3>\rho 4>\rho 5$. W-3 results show a thick package of unconsolidated sand deposits having good porosity and permeability for the aquifer but an increase in water salinity due to seawater intrusion, which decreases the resistivity of the layer (see Figure 7c).

\subsubsection{W-11 station}

This station data also represents four geological layers in which the topmost layer resistivity is $858 \Omega$ and it 

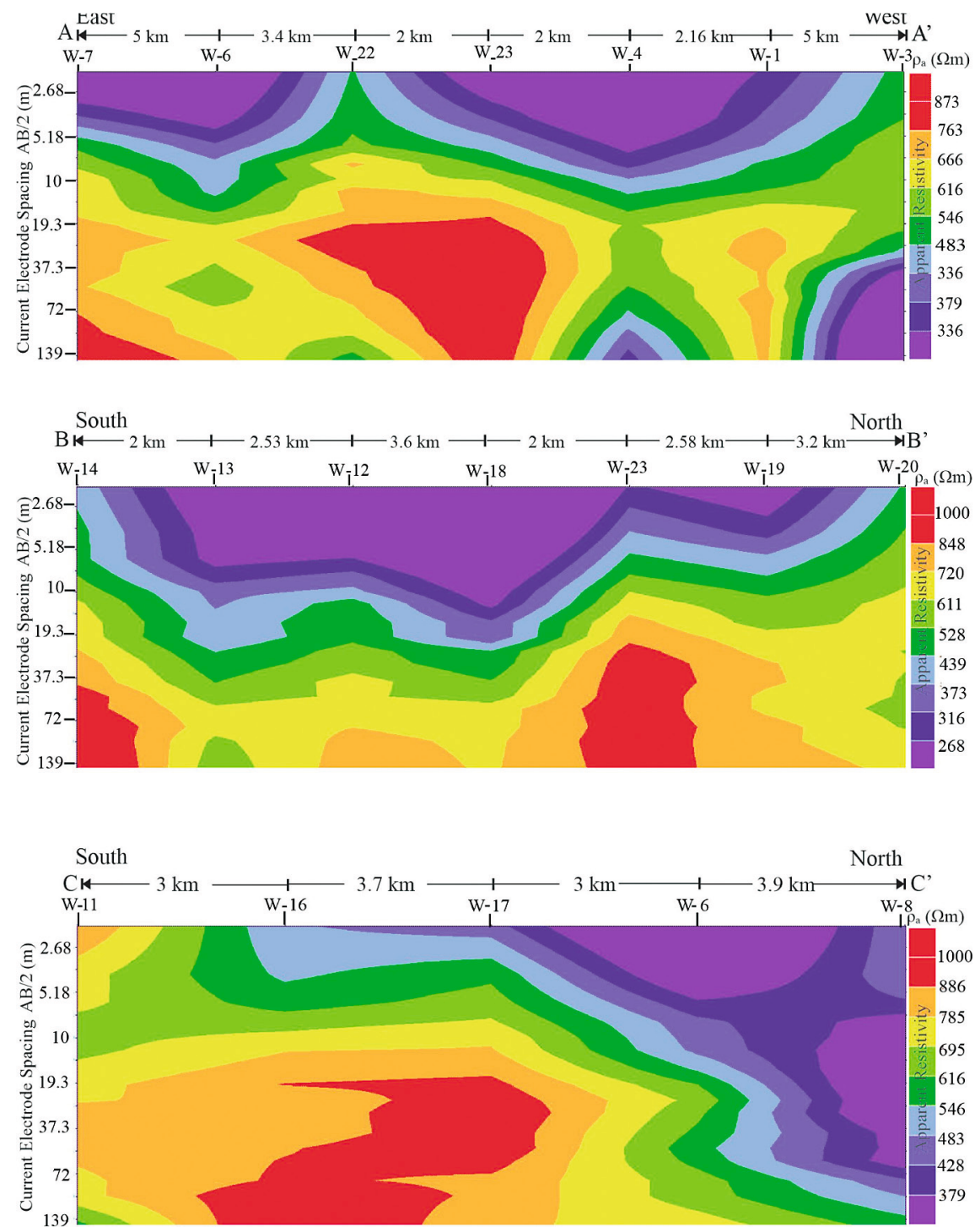

Figure 8: Pseudo sections of vertical Electric sounding (VES) profiles.

The $\mathrm{x}$-axis represents the distance between VES points, the Y-axis for subsurface depth in meter and colour bar shows the variation in apparent resistivity.

(a) A-A' East-West Pseudo section (b) B-B' north-south Pseudo section (c) C-C' north-south Pseudo section.

is interpreted as silty sand at a depth of 2.09 meters while layer 2 has a value of $596 \Omega \mathrm{m}$ which is silty sand present at a depth of 9.81 meters. Layer 3 has a resistivity value of $944 \Omega \mathrm{m}$ which is mixed sediment, initially silty sand and then sandy gravel present at a depth of 41.8 meters while layer 4 has a resistivity value of $656 \Omega \mathrm{m}$ which is sandy clay present at a depth of 105 meters. The curve type is $H K Q$, i.e. $\rho 1>\rho 2<\rho 3>\rho 4>\rho 5$. W-11 is interpreted as a thick package of unconsolidated sand and sandy gravel deposits. A higher resistivity below $41.8 \mathrm{~m}$ shows the potential presence of an unconfined aquifer (see Figure 7d).

The parameter of other VES stations (W-2, W-4, W-5, W-6, W-7, W-9, W-10, W-12-23) is summarized in Table 1. These parameters were obtained from the layer modelling of acquired field data (as adopted for $\mathrm{W}-1$, $\mathrm{W}-3, \mathrm{~W}-8, \mathrm{~W}-11)$. The resistivity values $\rho 3$, and $\rho 4$ are varying from 163-1125 ohm-m, which suggests the presence of sand and gravel lithology. The higher resistivity in $\rho 3$ and $\rho 4$ is identified as a saturated zone, where the thickness of h3 and h4 vary from 15.7 - $96.2 \mathrm{~m}$. The widespread thick package of sand and gravel is interpreted as an unconfined aquifer (James, 2000; Miller, 2000). In this case, where overlying unconsolidated sediments are permeable silty sand, sand and sandy gravel the aquifer recharge directly depends on surface water and rainfall (Cobourn et. al., 2017).

\subsection{Pseudo-section}

Three pseudo-sections have been generated along with three profiles (A-A', B-B', and C-C') by using 7 VES's in each profile (see Figures $8 \mathbf{8}, \mathbf{8 b}$, and $\mathbf{8 c}$ ). The pseudo-sections A-A' \& B-B' represent three zones, i.e. the topmost low resistivity zone, the middle medium re- 

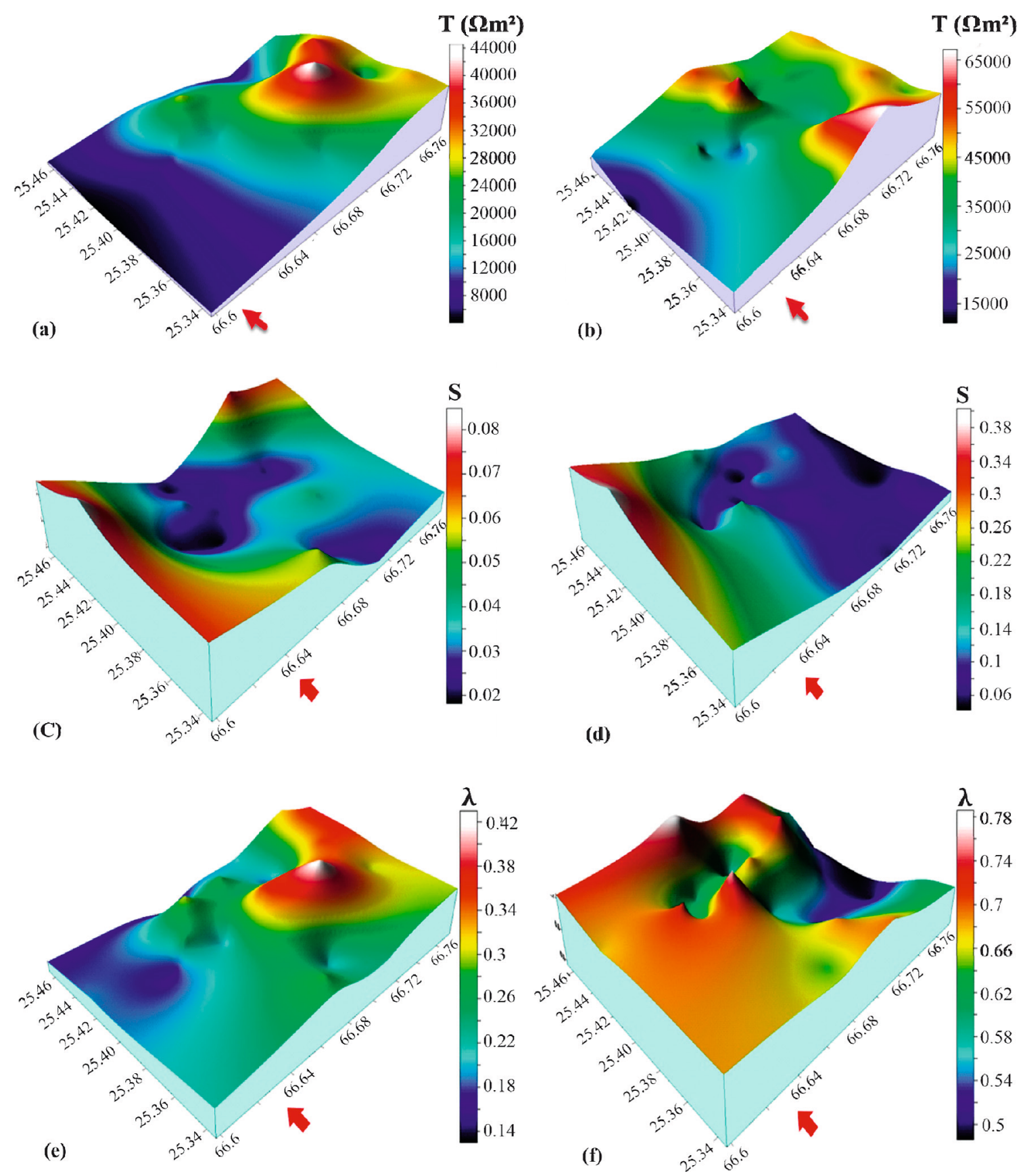

Figure 9: Transverse resistance ( $T$ ) surface map (a) 3D surface at $30 \mathrm{~m}$ depth

(b) $3 \mathrm{D}$ surface at $60 \mathrm{~m}$ depth; longitudinal conductance $(S)$ surface (c) $3 \mathrm{D}$ surface at $30 \mathrm{~m}$ depth

(d) ${ }_{3} \mathrm{D}$ surface at $60 \mathrm{~m}$ depth; Anisotropy surface (e) $3 \mathrm{D}$ surface at $30 \mathrm{~m}$ depth (f) ${ }_{3} \mathrm{D}$ surface at $60 \mathrm{~m}$ depth

sistivity zone, and the high resistivity zone in the centre (see Figures 8a and 8b). It is observed that the pseudosection A-A' represents a low resistivity trend toward the northwest of the study area, due to saline water intrusion. The pseudo-section B-B' shows contrasting resistivity zones in the middle of the section, and the high resistivity zones are interpreted as channel sand. The pseudo-section C-C' shows the water table at $40 \mathrm{~m}$ in the northeast of the study area. The high resistivity zone depicts a fresh water-bearing zone and the depth of the unconfined aquifer starts from $19-40 \mathrm{~m}$ in the study area. The VES points W-7, W-22, W-23, W-4, W-16, and
W-17 are located near the Winder River, one of the sources of recharge in the study area. The VES station near the river shows the presence of shallow water-bearing strata (see Figures 8a, 8b, and 8c) as compared to the stations away from the river.

\subsection{Dar-Zarrouk parameters}

Dar-Zarrouk parameters have been helpful in finding saline zones and observing variations in heterogeneity, average electrical properties of a single stratigraphic unit can be described by Dar-Zarrouk (D-Z) parameters. 

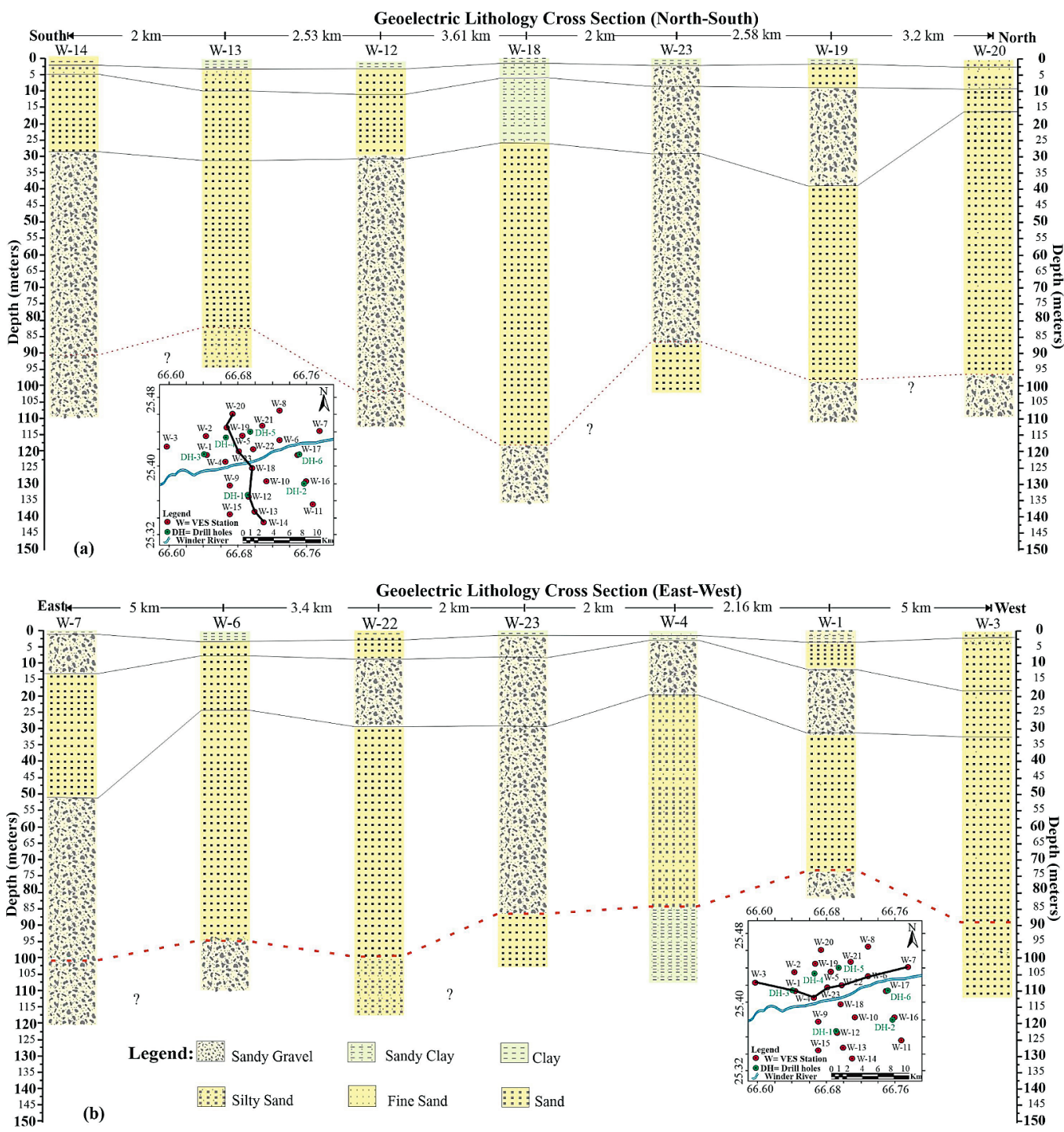

Figure 10: Geoelectric lithology cross-section (a) East-West geoelectric lithology cross section of 7 VES points (b) North-South geoelectric lithology cross section of 7 VES points.

(Maillet, 1947). Dar-Zarrouk parameters have been mapped at $30 \mathrm{~m}$ and $60 \mathrm{~m}$ depth for this area (see Figure 9). Transverse resistance and longitudinal conductance in $\mathrm{D}-\mathrm{Z}$ parameters are the resistance normal to the face and parallel to the face in a unit cross-sectional area. These parameters are also helpful in differentiating isotropic and anisotropic characteristics of subsurface lithology (Singh et al., 2004).

\subsubsection{Transverse Resistance (T)}

Transverse resistance has a strong relationship with the transmissivity of the aquifer and T-maps are normally utilized for delineating zones with high ground water potential (Braga et al., 2006; Toto et al., 2008). With the help of transverse resistance, the saline zone can also be interpreted as saline water values of $\mathrm{T}$ ranges from $2000 \Omega \mathrm{m}^{2}$ to $10,000 \Omega \mathrm{m}^{2}$ (Singh et al., 2004). The 3D surface map of transverse resistance has been prepared which shows low $\mathrm{T}$ values towards the south-west (So- miani and Damb areas) up to $8000 \Omega \mathrm{m}^{2}$ as an indication of high saltwater intrusion at shallow depths $(30 \mathrm{~m})$ (see Figure 9a) and low intrusion at a depth of $60 \mathrm{~m}$ (see Figure 9b). As values of T greater than $10000 \Omega \mathrm{m}^{2}$ represent freshwater, the 3D surface depicts that most of the area towards the east at $30 \mathrm{~m}$ and $60 \mathrm{~m}$ depth is covered by freshwater.

\subsubsection{Longitudinal Conductance (S)}

Longitudinal conductance (S) is the summation ratio of conductance to their respective resistivities and is used to delineate the clay and sand water aquifer region. In this case, an S-surface map from the interpreted results has been prepared (Slater, 2007; Yungul, 1996). The unit of conductance is seimens. The value of conductance increases towards the southwest which is an indication of salinity intrusion and decreases towards the east which represents the freshwater region (see Figure 9c \& 9d). 


\subsubsection{Anisotropy $(\lambda)$}

The anisotropic factor is defined as the ratio of resistivity measurement in two principal directions which are perpendicular to the bedding plane $(\rho t)$ and parallel to the bedding plane ( $\rho 1)$ (Maillet, 1947; Zohdy, 1965). The anisotropy $(\lambda) 3 \mathrm{D}$ surface has been prepared for 30 $\mathrm{m}$ (see Figure 9e) and $60 \mathrm{~m}$ depth (see Figure 9f). The anisotropy surface represents that most of the values are below 1 which indicates the homogenous and isotropic nature of the aquifer. The anisotropy and heterogeneity increase at a depth of $60 \mathrm{~m}$ mostly on the south-western side (towards the sea) (see Figure 9f).

\subsection{Geo-electric lithology Cross-section}

For understanding the subsurface geology and hydrogeological profile, geo-electric lithological cross-sections have been generated from the interpreted results. Figure 10a and Figure 10b represent four lithological units correlated in the study area. Seven lithological logs are correlated in two different profiles, i.e. north-south and east-west. These sedimentary deposits are affirmed by the braided Porali River in recent geological time (Ahsanullah, 1971). The north-south oriented profile (see Figure 10a) is showing that the sand is increasing as we are moving towards the seaside in the south. The east-west oriented profile (see Figure 10b) shows a similar lithological unit; however, their thicknesses vary. The thick sedimentary layer of sand and sandy gravel was identified as a potential unconfined aquifer of the study area.

\section{Conclusion}

The VES technique by using an electrical resistivity meter was utilized to delineate the hydrogeological conditions in the Winder area and to identify the aquifer characteristics. The acquired 23 VES stations were processed using IPI2Win to evaluate the subsurface layers for apparent resistivity, thickness, and depth. The results were calibrated with drilled log data to interpret the lithology. Pseudo-section and geoelectric cross-section constructed for the lateral distribution of lithology and apparent resistivity. Finally, the D-Z parameter was calculated for validation of the results and salinity intrusion in the aquifer of the study area. The concluded results show that the area is dominated by recent quaternary sediment and is mainly comprised of silty sand, fine sand, sandy gravel, and sandy clay. Layer-1 is interpreted as topsoil contained variable resistivity ranging at the VES station from about 63.6 to $516 \Omega \mathrm{m}$ and a thickness of less than $15 \mathrm{~m}$. Layer-2 is comprised of dry alluvium deposits with resistivity values of less than $1038 \Omega \mathrm{m}$ and a thickness greater than the surface layer. Layer-3 is an aquifer with geoelectric characteristics (resistivity ranges 219-1091 $\Omega \mathrm{m}$ ) and a depth of less than $45 \mathrm{~m}$ in most parts of the study area. Layer-3 corresponds to a satu- rated unconfined aquifer. The 4th layer resistivity was less than $1200 \Omega \mathrm{m}$ and comprised of thick sandy gravel and sand deposits. The locations for targeting potential zones with high groundwater flow are along the Winder River. The pseudo-sections show that the aquifers are present at a depth of $19 \mathrm{~m}$ near or along the Winder River and the potential of a freshwater aquifer decreases as one moves away from the river and towards the sea. The quality of the aquifer is expected to be freshwater whereas near the coastal area the aquifers are affected by seawater intrusion. D-Z parameter, T, with low values 8000 $\Omega \mathrm{m}^{2}$ towards the southwest (Somiani and Damb areas) also confirm the intrusion of seawater in the aquifer, whereas the high values indicate $10000 \Omega \mathrm{m}^{2}$ for a freshwater aquifer. The value of conductance increases towards the southwest which is an indication of high salinity and decreases toward the east which represents the freshwater zone. The anisotropy surface represents that most of the values are below 1 which represents the homogenous and isotropic nature of the aquifer. The hydrological conditions of the aquifer are interpreted in this study and may be helpful for the better planning of agriculture farms, the location of a tube well, groundwater modelling and its management in coastal areas to mitigate seawater intrusion in the region.

\section{References}

Abou El-Hassan, W. H., Mostafa, M.M., Fujimaki, H. and Inoue, M. (2009): Irrigation improvement assessment from the water quality and human health perspective in the Nile Delta. Food, Agriculture \& Environment, 7, 3-4, 815-822.

Afolayan, J.F., Olorunfemi, M. and Afolabi, O. (2004): Geoelectric/Electromagnetic VLF survey for groundwater in a basement terrain: A case study. Ife Journal of Science. 6, 1, 74-78.

Ahsanullah (1971): Report on landform and drainage basins in Karachi Region. Master Plan for Karachi Metropolitan Region, Karachi Development Authority, Karachi.

Ahsan, S.N. and Mallick, K.A. (1999): Geology and genesis of barite deposits of Lasbela and Khuzdar Districts, Balochistan, Pakistan. Resource Geology. 49, 2, 105-111.

Anomohanran, O. (2013): Geophysical investigation of groundwater potential in Ukelegbe, Nigeria. Applied Sciences. 13, 119-125.

Aoudia, M., Issaadi, A., Bersi, M., Maizi, D. and Saibi H. (2020): Aquifer characterization using vertical electrical soundings and remote sensing: A case study of the Chott Ech Chergui Basin, Northwest Algeria Journal of African Earth Sciences.

Barlow, P.M. and Reichard, E.G. (2010): Saltwater intrusion in coastal regions of north America. Hydrogeology. 18, 247-260

Bashir, E., Naseem, S. and Hamza, S. (2007): Hydrogeochemistry of the Winder river and adjoining tributaries, Balochistan, Pakistan. Chinese Journal of Geochemistry, 26, 3, 259-266. 
Battacharya, P.K. and Petra, H.P., (1968): Direct current geoelectrical sounding. Elsevier, Amsterdam, 131 p.

Benabdelouahab, S., Salhi, A., Himi, M., El Messari, J.S. and Ponsati A.C. (2019): Geoelectrical investigations for aquifer characterization and geoenvironmental assessment in northern Morocco Environ. Earth Sci., 78, 209 p.

Braga, A.C., Malagutti F.W., Dourado, J.C. and Chang, H.K. (1999): Correlation of electrical resistivity and induced polarization data with geotechnical survey standard penetration test measurements. Environmental and Engineering Geophysics, 4(2), 123-130.

Chen, D., Elhadj, A., Xu, H., Xu, X. and Qiao, Z. (2020): A Study on the Relationship between land use change and water quality of the mitidja watershed in Algeria based on GIS and RS. Sustainability, 12, 3510.

Choudhury, K., Saha, D.K. and Chakraborty, P. (2001): Geophysical study for saline water intrusion in a coastal alluvial terrain. Applied Geophysics, 46, 3, 189-200.

Clarke, R., Lawrence, A. and Foster, S.D. (1995): Groundwater a threatened resource. United Nations Environment Programme (UNEP) Environment. Library, 15 p.

Cobourn, K.M., Elbakidze, L. and Ghosh, S. (2017): Conjunctive Water Management in Hydraulically Connected Regions in the Western United States. In: Ziolkowska, J.R. and Peterson, J.M.: Competition for Water Resources Experiences and Management Approaches in the US and Europe. Elsevier Science, 278-297 p.

Dimitrios, Z. \& Hagedorn, K. (2016): Competition for Water Resources from the European Perspective.

El Baba, M., Kayastha, P., Huysmans, M. and De Smedt, F. (2020): Evaluation of the Groundwater Quality Using the Water Quality Index and Geostatistical Analysis in the Dier al-Balah Governorate, Gaza Strip, Palestine. Water, $12,262$.

El-Waheidi, M.M., Merlanti, F. and Pavan, M. (1992): Geoelectrical resistivity survey of the central part of Azraq basin (Jordan) for identifying saltwater/freshwater interface. Applied Geophysics, 29, 2, 125-133.

Famiglietti, J. (2014): The global groundwater crisis. Nature Clim Change 4, 945-948.

Frohlich, R.K. (1974): Combined geoelectrical and drill-hole investigations for detecting freshwater aquifers in northwestern Missouri. Geophysics, 39, 3, 340-352.

Gnos, E., Immenhauser, A. and Peters, T.J. (1997): Late Cretaceous/early Tertiary convergence between the Indian and Arabian plates recorded in ophiolites and related sediments. Tectonophysics, 271, 1-2, 1-19.

Gnos, E., Khan, M., Mahmood, K., Khan, A.S., Shafique, N.A. and Villa, I.M. (1998): Bela oceanic lithosphere assemblage and its relation to the reunion hotspot. Terra NovaOxford, 10, 2, 90-95.

Gopalakrishnan, T., Kumar, L. and Mikunthan, T. (2020): Assessment of spatial and temporal trend of groundwater salinity in Jaffna Peninsula and its link to paddy land abandonment. Sustainability, 12, 3681.

Hassan, E., Rai, J.K. and Anekwe, U.O. (2017): Geoelectrical Survey of ground water in some parts of Kebbi State Nigeria, a case study of Federal Polytechnic Bye-Pass Birnin
Kebbi and Magoro Primary Health Center Fakai Local Government. Geosciences, 7(5), 141-149.

Hasan, M., Shang, Y., Akhter, G. and Jin, W.J. (2019): Delineation of contaminated aquifers using integrated geophysical methods in northeast Punjab, Pakistan. Environmental Monitoring Assessment. 192, 12.

HSC (Hunting Survey Co. Ltd.), (1960): Reconnaissance geology of part of West Pakistan; A Colombo plan cooperative project, Canada.

Ihbach, F.Z., Kchikach, A., Jaffal, M., Elazzab, D., Khadiri, Y.O., Jourani, E., Pena Ruano, J.A., Olaiz, O.A. and Vizcaíno, D.L., (2020): Geophysical prospecting for groundwater resources in phosphate deposits (Morocco). Minerals, 10, 842 .

Jamal, N. and Singh, N.P., (2020): Electrical resistivity in the delineation of groundwater potential zones: a case study from Kota, Rajasthan, India. Arab. J. Geosci, 13, 697.

James, J.A. (2000): Groundwater atlas of United States. U.S. Geological Survey, Virginia. A-6 p.

Kaçmaz, H. and Eran Nakoman M. (2010): Shallow groundwater and cultivated soil suitability assessments with respect to heavy metal content in the Köprübaşi U mineralization area (Manisa, Turkey). Environmental Contamination and Toxicology, 85, 37-41.

Kazmi, A.H. and Abbasi, I.A. (2008): Stratigraphy \& historical geology of Pakistan (p. 524). Peshawar: Department. \& National Centre of Excellence in Geology, 524 p.

Kehinde, D., Oyeyemi, A., Ahzegbobor, P., Aizebeokhai, A., Metwaly, M., Oladunjoye, M.A., Bayo Solarin, B.A., Sanuade, O.A., Thompson, C.E., Ajayi, F.S. and Ekhaguere A.O. (2021): Evaluating the groundwater potential of coastal aquifer using geoelectrical resistivity survey and porosity estimation: A case in Ota, SW Nigeria. Groundwater Sustain, Dev.

Khan, M., Kerr, A.C. and Mahmood, K. (2007): Formation and tectonic evolution of the Cretaceous-Jurassic Muslim Bagh ophiolitic complex, Pakistan: Implications for the composite tectonic setting of ophiolites. Asian Earth Sciences, 31, 2, 112-127.

Keller, G.V. and Frischknecht, F.C. (1966): Electrical methods in geophysical prospecting. Oxford: Pergamon Press.

Koefoed, O., (1979): Geosounding principles 1: Resistivity sounding measurements Amsterdam: Elsevier Scientific, Elsevier Scientific Pub. Co. 276 p.

Long, M., Donohue, S., L' Heureux, J., Solberg, I., Rønning, J., Limacher, R., O’Connor, P., Sauvin, G., Romoen, M. and Lecomte, I. (2012): Relationship between electrical resistivity and basic geotechnical parameters for marine clays. Canadian Geotechnical Journal, 49, 1158-1168.

Maillet, R. (1947): The fundamental equations of electrical prospecting. Geophysics. 12(4), 529-556.

Mali, P.D. and Mujawar, K.C. (2019): Assessment of rainwater harvesting in Ray Nagar, Kumbhari, Solapur, Maharashtra, India. Information and Computing Science, 6, 4, 35-44.

Massoud, E.C., Liu, Z., Shaban, A. and Hage, M.E. (2021): Groundwater Depletion Signals in the Beqaa Plain, Lebanon: Evidence from GRACE and Sentinel-1 Data. Remote Sensing, 13, 915. 
Meindinyo, R.O.K., Utuedeye O. and Adedokun I.O. (2017): Vertical Electrical Sounding for the determination of underground Resistivity in part of Nigeria Wilberforce Island, Amassoma, Bayelsa State. Research \& Method in Education, 53-61.

Miller, T.S. (2000): Simulation of Ground-water Flow in an Unconfined Sand and Gravel Aquifer at Marathon, Cortland County, New York. U.S. Geological Survey.

Morgan, L.K. and Werner, A.D. (2015): A national inventory of seawater intrusion vulnerability for Australia. Hydrology: Regional Studies, 4, 686-698.

Muzzillo, R., Zuffianò, L.E., Rizzo, E., Canora, F., Capozzoli, L., Giampaolo, V., De Giorgio, G., Sdao, F. and Polemio, M. (2021): Seawater Intrusion Proneness and Geophysical Investigations in the Metaponto Coastal Plain (Basilicata, Italy). Water, 13, 53.

Rhett, H. (2001): An Introduction to electrical resistivity in geophysics. American Journal of Physics.

Shah, S. I. (1977): Stratigraphy of Pakistan. Quetta, Pakistan: Director General, Geological Survey of Pakistan.

Sheth, H.C. (2008): Do major oxide tectonic discrimination diagrams work? Evaluating new log-ratio and discriminantanalysis-based diagrams with Indian Ocean mafic volcanics and Asian ophiolites. Terra Nova, 20, 3, 229-236.

Singh, U.K. and Das, R.K., \& Hodlur, G.K. (2004): Significance of Dar-Zarrouk parameters in the exploration of quality affected coastal aquifer systems. Environmental Geology, 45, 5, 696-702.

Slater, L. (2007): Near surface electrical characterization of hydraulic conductivity: From petrophysical properties to aquifer geometries, A review. Surveys in Geophysics, 28, 2-3, 169-197.

Solberg, I.L., Ronning, J.S., Dalsegg, E., Hansen, L., Rokoengen, K. and Sandven, R. (2008): Resistivity measurements as a tool for outlining quick-clay extent and valley-fill stratigraphy: a feasibility study from Buvika, central Norway. Canadian Geotechnical, 45,2, 210-225.

Soupios, P.M., Kouli, M., Vallianatos, F., Vafidis, A. and Stavroulakis, G. (2007): Estimation of aquifer hydraulic parameters from surficial geophysical methods: A case study of Keritis Basin in Chania (Crete-Greece). Hydrology, 338, 1-2, 122-131.

Spate, O.H.K., (1956): India and Pakistan. Methuen, London.

Telford, W., Geldart, L. and Sheriff, R. (1990): Applied geophysics. Cambridge University Press.

Toto, E.A., Kerrouri, C., Zouhri, L., Basri, M.E., Ibenbrahim, A., Mohamad, H. and Benammi, M. (2008): Geoelectrical exploration for groundwater in Al Maha Forest, Ain Jouhra, Morocco. Hydrological Processes, 22, 11, 1675-1686.

Youssef A.B., Benamara, A., Ammar, A., Hrittta, D., Ibrahim, D. and Bouikbane, H. (2021): Application of Vertical Electrical Sounding Resistivity Technique to Explore Groundwater in the Errachidia basin, Morocco. Groundwater for Sustainable Development, 15.

Young, M.E., De Bruijn, R.G. M. and Al-Ismaily, A.S. (1998): Exploration of an alluvial aquifer in Oman by time-domain electromagnetic sounding. Hydrogeology, 6, 3, 383-393.

Yungul, S.H. (1996): Electrical methods in geophysical exploration of deep sedimentary basins. Springer.

Zohdy, A. and Jackson, D.B. (1969): Application of deep electrical soundings for groundwater exploration in Hawaii. Geophysics, 34, 4, 584-600.

Zohdy, A. (1965): The auxiliary point method of electrical sounding interpretation, and its relationship to the DarZarrouk parameters. Geophysics, 30, 4, 644-660. 


\section{SAŽETAK}

\section{Studije istraživanja podzemnih voda i prodora slanosti s pomoću istraživanja električnoga otpora (ERS), slučaj područja Winder, Beludžistan, Pakistan}

Izvori podzemne vode uvijek su se istraživali radi njihove upotrebe u kućne i poljoprivredne svrhe. U ovoj je studiji područje Windera u Beludžistanu, uz obalu priobalnoga bazena Inda, istraženo korištenjem metode električnoga otpora radi dubljega razumijevanja hidrogeoloških i hidrogeofizičkih uvjeta. Nizovi elektroda Schlumberger korišteni su za prikupljanje podataka o vertikalnome električnom sondiranju za 23 različita mjesta u ovome području. Podatci na terenu kalibrirani su teoretskim krivuljama tijekom obrade s pomoću softvera s grafičkim sučeljem. Iz obrađenih podataka izdvojena je stvarna otpornost, dubine, debljine, svojstva vodonosnika, vrsta tla i kvaliteta podzemne vode. Za bočnu raspodjelu hidrogeoloških postavki stvoreni su pseudopresjeci i geoelektrični litološki odsjeci. Nadalje, izrađeni su proračuni Dar-zarroukovih parametara i generirane su 3D površine na dubini od $30 \mathrm{~m}$ i $60 \mathrm{~m}$ za poprečni otpor $(\mathrm{T})$, uzdužnu vodljivost (S) i anizotropiju ( $\lambda$ ). Ti su parametri ucrtani za raspodjelu otpora i analizu upada slane obale. Rezultati sondiranja prikazuju četiri sloja uglavnom sastavljena od muljevitoga pijeska, pjeskovite gline, pijeska i pješčanoga šljunka, a dubina se kreće od o do $110 \mathrm{~m}$. Tumačenje ilustrira da su slatkovodni vodonosnici prisutni u kvartarnim pjeskovitim i pjeskovitim naslagama šljunka. Vodeni je sloj na maloj dubini uz rijeku, a dublje na sjeveroistoku i dalje od rijeke Winder. Otpornost se kreće od 29 do $1091 \Omega \mathrm{m}$ u sloju 3, što se tumači kao zasićena zona. Približni je domet vodostaja 19 - 30 m. Viša vrijednost T veća od 10000 pokazuje slatku vodu i nisku vrijednost 8200 za prodiranje slanosti na jugozapadu prema moru.

\section{Ključne riječi:}

podzemne vode, okomito električno sondiranje, Winder, Dar-zarroukov parametar, poljoprivredno gospodarstvo

\section{Author contribution}

Muhammad Irfan (PhD, scholar/Assistant Professor, Geophysics) conducted an electrical resistivity survey for data acquisition, processing, field mapping on a log-log graph and drilled log collections from a nearby borehole. Salma Hamza (PhD, Associate Professor, Environmental Geology) provided the acquisition plan and conducted the resistivity survey. Waqar Azeem (Lecturer, Geology) performed the mapping and analysis of the Dar-Zarrouk parameter. Shaista Mahmud (Senior Assistant Professor, Geophysics) provided the geology of the area. Syed Nawaz ul Huda (PhD, GIS Analyst) provided the methodology and software analyses. Anwar Qadir (Assistant Professor, Hydrogeology) constructed the geo-electric lithology cross-section. 